\title{
Effect of weed management practices on weed control, growth attributes, yield and economics in Rabi groundnut (Arachis hypogaea L.)
}

\author{
T.K. SAMANT*, B.C. DHIR AND B. MOHANTY \\ Krishi Vigyan Kendra (O.U.A.T), ANGUL (ODISHA) INDIA
}

\section{ARITCLE INFO}

Received : 03.07 .2015

Revised : 18.08 .2015

Accepted : 03.09 .2015

\section{KEY WORDS :}

CGR, Dry weed biomass, Economic, Groundnut, Quizalofop-ethyl, WCE

*Corresponding author:

Email: tksamant_2003@yahoo.co.in

\begin{abstract}
A field trial was conducted during Rabi season of 2013-14 in farmer's field in Sandhapal village of Chhendipada block in Angul district in Odisha to study the effect of weed management practices on weed control, growth attributes, yield and economics in Rabi groundnut.The treatments comprised of different weed management practices viz., $\mathrm{T}_{1}$ - Post-emergence application of quizalofop ethyl $0.05 \mathrm{~kg} \mathrm{ha}^{-1} f b$ one hand weeding at $25 \mathrm{DAS}, \mathrm{T}_{2}$ - Farmers practice of one hand weeding at $25 \mathrm{DAS}$ and $\mathrm{T}_{3}$-Weedy check. The experimental trial was laid out in Randomized Block Design with thirteen replications. The results revealed that post-emergence application of quizalofop ethyl $0.05 \mathrm{~kg} \mathrm{ha}^{-1} \mathrm{fb}$ one hand weeding at 25 DAS recorded maximum weed control efficiency $(71.4 \%)$ with minimum dry weed biomass $\left(79.2 \mathrm{~g} \mathrm{~m}^{-2}\right)$ at harvest. The same treatment also produced significantly higher pod yield $\left(22.34 \mathrm{q} \mathrm{ha}^{-1}\right)$, plant height $(40.13 \mathrm{~cm})$, number of pods plant ${ }^{-1}(19.5), 100$ pod weight $(81.7 \mathrm{~g}), 100$ seed weight $(36.2 \mathrm{~g})$, total dry matter accumulation( 2.16 to $25.5 \mathrm{~g} \mathrm{plant}^{-1}$ ), CGR (5.32 to $26.40 \mathrm{~g} \mathrm{~m}^{-2}$ day $^{-1}$ ), gross return (Rs. 89360 ha $^{-1}$ ) and B:C ratio(2.20) with additional net return of Rs. 10280 ha $^{-1}$ as compared to farmers practice and weedy check. Thus, application of quizalofop ethyl 5 per cent $1.0 \mathrm{~kg} \mathrm{ha}^{-1} f b$ one hand weeding appeared to be effective, economically viable for weed control, crop growth, higher pod yield and net profit.
\end{abstract}

How to view point the article : Samant, T.K., Dhir, B.C. and Mohanty, B. (2015). Effect of weed management practices on weed control, growth attributes, yield and economics in Rabi groundnut (Arachis hypogaea L.). Internat. J. Plant Protec., 8(2) : 307-312. 